\title{
The Effect of Classcraft on Enhancing Grammar Performance of Adult Learners
}

\author{
I Witari, K Anwar and Y Arifani \\ Universitas Muhammadiyah Gresik, East Java, Indonesia \\ Corresponding author: khoirulanwar@umg.ac.id
}

\begin{abstract}
This study aims to investigate the effect of Classcraft on enhancing grammar performance of adult learners. A quasiexperimental study employed involved 27 adult learners from graduate and postgraduate program. The participants were from beginner level and divided into Control Group (14 learners) and Treatment Group (13 learners). Data collection instruments were pre-test and post-test scores and a questionnaire. The result of Independent T-test revealed that there was statistically significance difference on the post-test scores between the Control Group and Treatment Group at significance level of 0.05 indicating that the implementation of Classcraft improved grammar performance of adult learners. The findings propose that a learning process that gives adult learners a sense of competitiveness, autonomy, recognition, competence, and relatedness can enhance adult learners' learning performance The result of the questionnaire showed that overall, adult learners have positive attitude towards the implementation of Classcraft in the class. Future studies could be conducted by combining different gamification platforms into one course to maintain an element of surprises or by applying the gamification across different level of proficiency.
\end{abstract}

Keywords: Grammar performance, adult learners, gamification, Classcraft

\section{INTRODUCTION}

Grammar is considered the basic element in learning English since it helps learners to master the skills (reading, writing, speaking) needed to effectively comprehend English [1,2]. Instructions of grammar also play an important role in SLA in that learners can use them to construct sentences to express themselves correctly [3].

For many adult learners, learning grammar is essential because they realize its social value [4]. Furthermore, mastering grammar can be beneficial for adult learners' career in terms of employment, promotion, and their academic achievement [4,5]. Notwithstanding its importance in language learning, grammar is still considered a difficult subject to learn since its technical language and intricate rules can be daunting. In addition, during the teaching and learning process, grammar can be demotivating for both teacher and learners [6]. Cozma [7] stresses that when adult learners become the learners in a language classroom, the teaching process tends to be problematic; yet, it is also fascinating and satisfying.

Countless teachers have tried to change the classroom atmosphere into something more comforting, pleasurable, and exciting in dealing with teaching grammar to adult learners. One of the ways to lift the classroom's mood is by applying gamification on the learning process. The use of gamified teaching approach enhances the effectiveness of learning process experienced by adult learners because gamified activities engage learners to activate their cognitive ability [8]. It is argued that applying game elements to a classroom setting helps improve learners motivation [9-11] and gives learners excitement in the learning process [12].

Despite the innumerable studies conducted on the effect of gamification on learner performance [1], [13-15], the studies in this field are mostly conducted on children, teen or young adults. The growing number of adult learners in formal and non-formal education seems to be overlooked by scholars and the prospect of applying gamification to uphold adult learning has not been delved into.

Classcraft together with Kahoot!, Rezzly, Seppo and Youtopia, is a favorite educational digital game platform [16]. A number of studies on the effect of Classcraft on educational settings have shown positive results on improving student motivation [1719], student engagement [20], and student performance [21]. This brings to the notion of conducting a study to investigate the effect of using Classcraft to enhance adult learner performance in learning grammar. 


\section{LITERATURE REVIEW}

\subsection{Teaching Grammar in EFL}

Grammar has been an important part of a language since it is often believed as the forms and rules of a language. It is an accurate description; however, grammar is not merely about the structuring of a language. Not only is grammar a structure of rules controlling how words are arranged and associated in a sentence [22,23], but it is also "a system of meaningful structures and patterns that are governed by particular pragmatic constraints" [24]. Grammar can be viewed both as knowledge and ability [25]. While grammatical knowledge focuses on learning the rules for sentence construction, grammatical ability describes the use of grammar as a resource to create texts in both spoken and written forms.

Even though previous studies were made public that grammar teaching promoted language performance [26,27], it is widely assumed that grammar is not helpful and necessary [6], [28]. Grammar was also considered meaningless and had decontextualize forms that were secluded from use [6]. Further, Saeedi and Biri [6] stated that the presence of Communicative Language Teaching method contributed to this figment and made grammar to stay on the sideline of the language learning scene. Zero-option principle by Rod Ellis and input hypothesis by Stephen Krashen [22] might inspire the proponents of CLT method to think this way. However, studies conducted by Long [29] and Ellis [30] in SLA research have led to a reawakening of grammar teaching [31].

In light of grammar teaching, Özkan [32] claimed that grammar was one of the most challenging aspects to teach and its role in teaching and learning languages was essential. Azar [33] highlighted the importance of grammar teaching in helping learners uncover the nature of language consisting of predictable patterns of what people hear, say, read, and write comprehensibly. She claimed that grammar was the knitting that makes yarns into the fabric, and without it, there were only individual words, sounds, pictures, or gestures to communicate meaning. According to Richard, J., and Renandya [34], people now concur that grammar is crucial and unignorable, and lack of grammar's knowledge makes learner's language development inhibited. These reasons make grammar teaching an essential part in learning a foreign language.

\subsection{Principle of Adult Learners}

Andragogy, a term introduced by Knowles [35] as opposed to pedagogy, emphasizes that the way of adult learners in acquiring knowledge is different and distinct from that of younger ones. Therefore, teachers should employ methods suitable for adult learning style. Some of the principles of adult learners as explained by Knowles [35] are selfdirected in which they can guide and lead their own learning process; full of life experiences that can help them navigating their learning process; ready to learn when they are directed by new social roles; problem-centered instead of subject-centered meaning that they focus more on the task or assignment in the learning process; and internally motivated. Likewise, adult is more likely to have characteristics such as autonomous, self-directed, and goal-oriented [8].

\subsection{Gamification}

Gamification is a newly coined term used to describe the implementation of game components, such as game psychology, game mechanics, and game dynamics to non-game situation [36]. Gamification is the process of incorporating game mechanics and game thinking into activities aside from non-game situations to increase student engagement and solve problems [37]. Gamifications can also be defined as the utilization of game mechanics and experience design to engage people digitally and to motivate people to attain their goals [38].

Gamification garners attention due to its ability to affect behavior and provide successful outcomes. Games stimulate strong emotional responses, such as frustration, curiosity, and joy [39]. In addition, people's productivity and engagement increase when playing game [40].

The indispensable reasons to promote gamification in educational setting are its stimulating components, such as instant feedback, contentment, challenge, and triumph [41]. Gamification in educational settings poses a number of benefits, such as increased excitement, unperturbed atmosphere, more noticeable learning progress, and more ownership of learning [42]. Additionally, gamification can be used to give rewards for expected behavior and to assure that these behavior facilitate learners to achieve intended learning outcomes [43], [44]. By applying gamification in the teaching learning process, learners can study in a more relaxed atmosphere. This will lead to a better 
engagement in the lesson taught and result in an intended learning outcome. As learners now are accustomed to interactive media and games, classroom gamification might interest and motivate them [45].

\subsection{Classcraft}

Classcraft, a cloud-based digital game platform that operates across various devices, is one of five popular educational digital game platforms [16]. It is designed as an educational tool for learners. Since Classcraft is working in a browser connected to the internet, it does not require any installation unless one chooses to use it as a mobile app. Classcraft has been successfully employed in primary, school, high school, and even several university courses.

The main theme and general model of Classcraft is inspired by role-play game (RPG) and it is named after a massively popular multiplayer online roleplaying game (MMORPG), World of Warcraft. Shawn Young created the first version of Classcraft in January 2011 for personal use. Classcraft works as augmented reality and employs a layer of fantasy over life in the classroom [17], [18]. The main objective of Classcraft is to make the learning atmosphere engaging and reflexive and to stimulate the collaboration among learners [46].

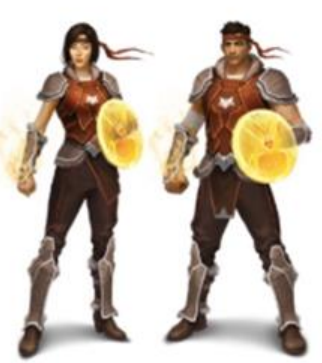

Warrior 80 HP 30 AP

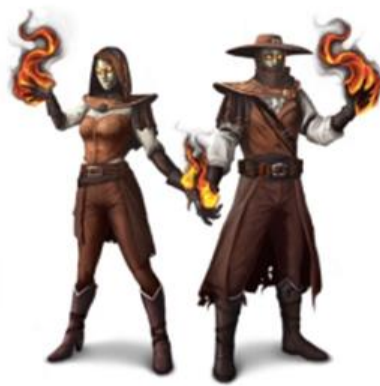

Mage

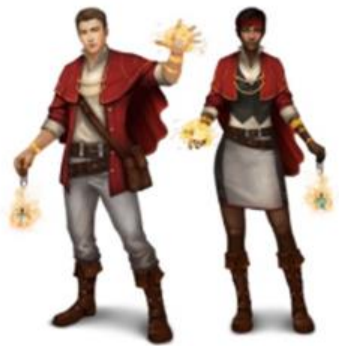

Healer 50 HP 35 AP

FIGURE 1. The Interface of Classcraft Teacher's Account

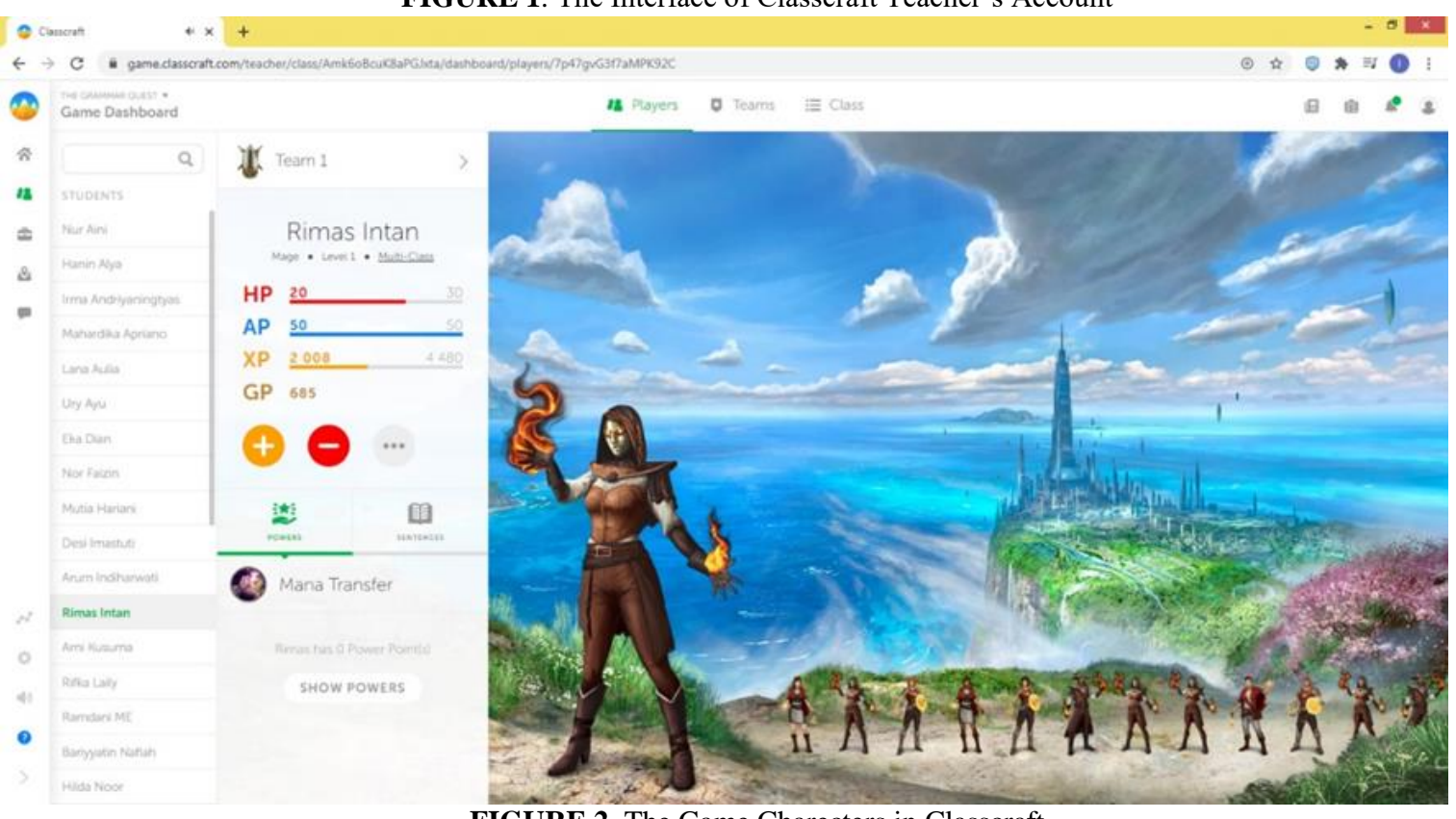

FIGURE 2. The Game Charecters in Classcraft

Usually, learners are divided into teams consisting of 4-6 learners. Learners are then given an opportunity to decide which game character they want to play, a warrior, a mage or a healer. Different 
personas have their own unique set of powers and diverse rewards to support their team. Just like any other game, each character has five attributive cores namely XP (Experience Points), AP (Action Points), HP (Health Points), PP (Power Points), and GP (Gold Points). XP is used for levelling up; AP is for using student's power; HP is for representing student's energy life; PP is for unlocking new powers; and GP is for customizing student's avatar

In addition to basic game elements such as PBL (point, badge, and leaderboard), Classcraft also provides other game elements such as instant feedback, quest, avatar, and reward. Classcraft is not only incorporating reward-based component but it also attempts to make student intrinsically motivated by allowing learners to manage their own learning process [16]. This philosophy, primarily used in video games, is based on Self-Determination Theory [47] postulating human's innate needs for competence, autonomy and relatedness. Competence is human's need to control the environment and form a desirable outcome; autonomy is the desire to act based on individual's will and interest; relatedness is the sense of belonging to a group or related to others. Another advantage of Classcraft is the design of Classcraft that is purposely created to manage courses, maintain learners' presence in the class and involve learners' participation during the learning process [48].

\subsection{Related Research}

Ortiz-Rojas et al. [49] conducted research to review 23 studies related to gamification focusing on learning performance. They argued that overall adding game elements into learning process demonstrated a promising improvement in learning performance, given certain situations.

Hashim et al. [14] conducted a study to investigate the effect of gamified-learning on grammar improvement to 30 secondary school students in Malaysia using Kahoot!, PowerPoint Challenge Game and Socrative. They found out that the application of those digital games increased grammar achievement. Similarly, a study to examine the impact of gamification on grammar performed by Zarzycka-Piskorz [15] also revealed that the implementation of gamification was highly effective on the grammar learning process. The samples of the study were 102 university students studying grammar in Pedagogical University in Krakow, Poland.

While studies on the effect of gamification on adult learners' performance were limited, the prevailing studies yielded constructive results. Mora et al. [50] proved that 60 adult learners whose age ranging from 22-53 had a positive attitude towards the gamification design and showed a great level of engagement after studying a software engineering course for one semester. Ge [51] investigated whether adult learners could have a better performance if reward strategy, one of gamification's components, was applied in the learning process. The subject of Ge's study was 180 adult e-learners with the age ranging from 25 to 38 years old studying grammar online at an e-learning college in Beijing. The study exhibited that applying reward strategy substantially improved learners' performance.

There are not many studies regarding the effect of Classcraft on English as a Foreign Language, let alone focusing on grammar performance. Montosa Lirola [19] carried out research about the using of Classcraft on EFL class to 29 learners in secondary school in Palma de Mallorca, Spain. However, the focus of the research was learners' motivation and their perception of Classcraft. Overall, the result revealed that Classcraft had a positive impact on their motivation.

\section{METHODOLOGY}

This study aims to investigate whether the implementation of Classcraft had a significant effect on the grammar performance of adult learners.

\subsection{Research Questions}

The study aims to address the following questions:

1. Does the implementation of Classcraft have a positive effect on enhancing grammar performance of adult learners?

2. What are adult learners' attitudes towards the use of Classcraft on grammar learning?

\subsection{Participants}

The population of this research comprised 120 graduate and post graduate students, first-year students from 2019/2020 academic year who participated in a free training program to improve their English. They were from various departments: immunology, law, nursing, public policy, sharia economics, pharmaceutical science, and public health. 
The samples of this study were chosen randomly with a cluster random sampling technique from the beginner classes. The control group consisted of 14 students (9 females and 5 males) and the treatment group comprised 13 students $(8$ females and 5 males). The students were between 22 and 54 years old with the average age was 27 years old. They had studied English at least for 6 years during their secondary school and Bahasa Indonesia is their native language.

TABLE 1. Distribution of Research Participants

\begin{tabular}{|l|l|l|}
\hline \multirow{2}{*}{ Groups } & \multicolumn{2}{|l|}{ Participants $(\mathrm{N}=27)$} \\
\cline { 2 - 3 } & Male & Female \\
\hline Control Group (CG) & 5 & 9 \\
\hline Treatment Group (TG) & 5 & 8 \\
\hline
\end{tabular}

\subsection{Design and Procedure}

This study was quantitative research using a quasiexperimental-control group with a pre-test and a post-test design. A quasi-experimental design is an experimental study involving manipulation of independent variables with non-randomized subjects assigned to treatment group [52]. Furthermore, Ary et al [52] argue that a quasi-experimental design allows researchers to attain a sensible conclusion despite its lack of full control. Students in treatment group participated in an ELPT preparation class using Classcraft, while learners in control group attended a regular class without the gamification technique. At the end of the course, students from TG were given a questionnaire to know their attitude towards the use of Classcraft in the class. The questionnaire used was developed by Saovapa Wichadee and Fasawang Pattanapichet from Bangkok University. The questionnaire used a 5likert-scale with point 1 for most disagree and point 5 for most agree. There were seven items in the questionnaire and students were to choose one out of five scales that most likely described their attitude.

Prior to the training, all students were given a pre-test to measure their proficiency level. The pretest consisted of 40 grammar questions. Students were then divided into 7 classes consisting of 13 18 students each. There were 1 intermediate class and 6 beginner classes. To identify the improvement in the grammar performance after joining thetraining, students had to take a post-test. The validity of both tests was approved by three experts from English departments of Universitas Airlangga. Both pre-test and post-test had been tried out to English teachers and students from English department before administered to students.

The materials for the training were compiled from various books focusing on grammar mastery such as one clause and multiple clauses; part of speech especially about subject, verb, adjective, and verb; and agreement. The training is held four times a week for 100 minutes each and lasts for 3 weeks.

Both control and treatment groups followed the same lesson plans in accordance with the textbook. The textbook contains not only materials but also practices and exercises on the subjects taught. The control group studied in a conventional method, relying only on textbooks. In addition to studying the textbook, the treatment groups also used Classcraft as a tool to help them understanding the materials. At the end of every meetings, students would do exercises about the materials taught. Students in the control group worked individually to answer questions on the review section of the book and after that the teacher either read the answer key for the students or discussed the answer of the questions one by one with the class. In the treatment group, students did the exercises in the form of Boss Battle activity in Classcraft displayed on the screen for the whole class to see. 

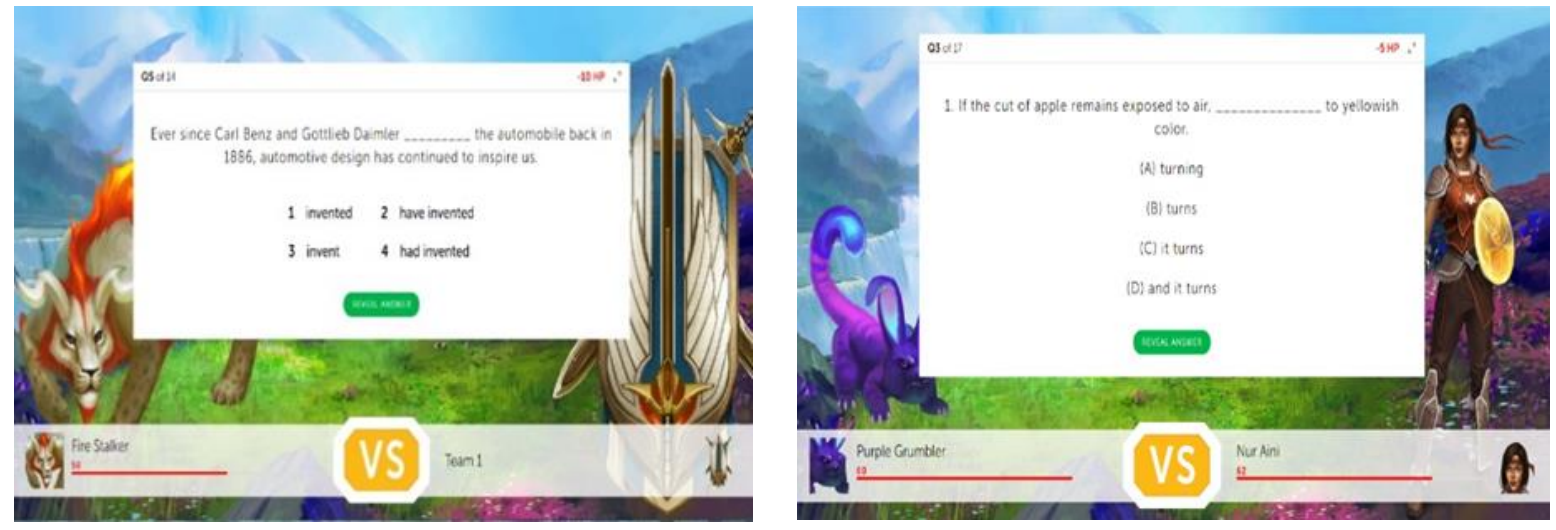

FIGURE 3. Display of Boss Battle for the Team (Above) and Individual (Below)

Boss Battle was one of the tools in Classcraft that could make review exercises enjoyable and exciting. It was an entertaining way to assess students' understanding of the materials taught and it can help them to prepare for the test. Moreover, playing Boss Battle gave the teacher opportunity to observe cooperation and autonomy. Teacher could choose whether to play it in an individual mode or a team mode. In the individual mode, the name of the student would appear randomly on a given question, whereas on the team mode, the name of the team would appear arbitrarily on a random question. In team mode, students could discuss the answer with the other members of the team.

The purpose of the Boss Battle activity was to defeat a boss. Teacher had to set the boss' HP (Health Point) when transforming exercise in the textbook into a Boss Battle activity. When a student or a team answered a question correctly, it would create a damage to the boss resulting in the decrease of the boss' HP. On the contrary, when students or teams gave a wrong answer, their HP would decrease. When the boss' HP turned to 0, the class won the battle, and all students would be rewarded with rewards, such as GP and XP points.

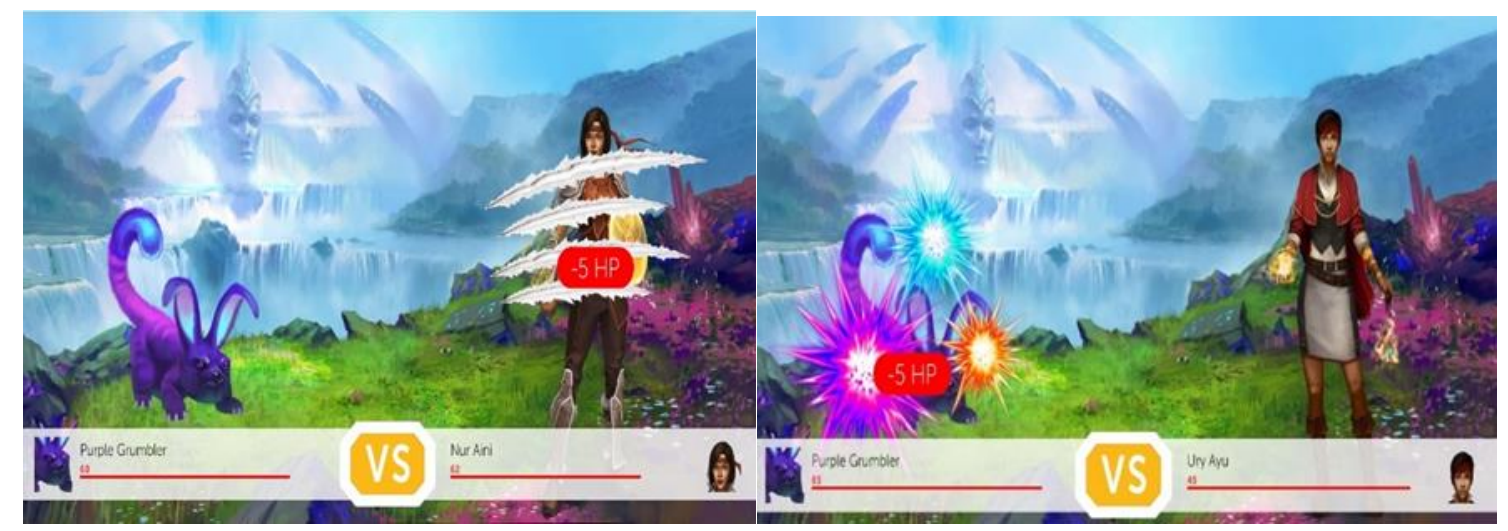

FIGURE 4. Display of the Damage Taken by the Boss When Students Chose the Correct Answer (Above) and When Students Chose the Wrong Answer (Below)

\subsection{Data Collection}

To know whether the treatments had significantly affected students' grammar performance, a statistical calculation was applied. After the pre-test and posttest scores were collected, they were then evaluated using SPSS version 24.0. The first step was to calculate the normality and the homogeneity of the data. To find out the normality of the data distribution, Saphiro-Wilk test was employed since studies show that Shapiro-Wilk test has better performances in most situation [53]. The significance level used to interpret the data was 0.05 
[54]. As for the homogeneity test, Levene's test was used to identify the equality of variances throughout the samples. The next step was to pinpoint the mean difference of students' score between the pre-test and post-test using the paired-sample T-test. This aimed to tell whether there was a significant improvement in the grammar's score after the treatment was given to the groups. The last step was to test the hypothesis using independent sample ttest.

\section{RESULTS}

The result of the normality and homogeneity test for control and treatment group was presented in table 2 .

TABLE 2. The Normality Test of Pre-test and Post-test

\begin{tabular}{|l|l|l|l|l|}
\hline \multicolumn{3}{|c|}{ Groups } & \multicolumn{3}{|c|}{ Shapiro-Wilk } \\
\cline { 3 - 5 } & $\mathrm{N}$ & Statistics & Sig \\
\hline $\begin{array}{l}\text { Control } \begin{array}{l}\text { GG) } \\
\text { (CG) }\end{array} \\
\text { Treatment } \begin{array}{l}\text { Group } \\
\text { (TG) }\end{array}\end{array}$ & Pre-test & 14 & 0.898 & 0.106 \\
\cline { 2 - 5 } & Post-test & 14 & 0.944 & 0.478 \\
\cline { 2 - 5 } & Pre-test & 13 & 0.944 & 0.506 \\
\cline { 2 - 5 } & Post-test & 13 & 0.926 & 0.300 \\
\hline
\end{tabular}

Table 2 shows the result from the normality test using Shapiro-Wilk. The p-value was 0.106 for the CG pre-test and 0.478 for the CG post-test, while for $\mathrm{TG}$, the p-value for the pre-test was 0.50 , and for the post-test was 0.300 . The p-value from pre-test and post-test for both control and treatment groups was greater than the significance level of 0.05 . This specified that the data have normal distribution.

TABLE 3. The Homogeneity Test

\begin{tabular}{|l|l|l|l|l|}
\hline & $\begin{array}{l}\text { Levene } \\
\text { Statistic }\end{array}$ & df1 & df2 & Sig. \\
\hline Pre-test & 1.542 & 1 & 25 & 0.226 \\
\hline Post-test & 0.085 & 1 & 25 & 0.773 \\
\hline
\end{tabular}

Table 3 demonstrates the p-value of homogeneity test. The value was 0.226 for pre-test and 0.773 for post-test, higher than the significance level of 0.05 , indicating that the data were homogeneous.

TABLE 4. Descriptive Statistics

\begin{tabular}{|l|l|l|l|l|}
\hline Group & Mean & $\begin{array}{l}\text { Mean } \\
\text { DIfference }\end{array}$ & $\mathrm{N}$ & Std.Deviation \\
\hline Pre-test CG & 38,36 & 2,929 & 14 & 2.437 \\
\hline Post-test TG & 41,29 & & 14 & 3.407 \\
\hline Pre-test CG & 35,92 & \multirow{2}{*}{9.000} & 13 & 3.796 \\
\hline Post-test TG & 44,92 & & 13 & 3.570 \\
\hline
\end{tabular}

Table 4 reveals that the means of students' post-test scores are higher than those of students' pre-test score. There was a significant difference in the scores in $\mathrm{CG}$ for pre-test $(\mathrm{M}=38.36, \mathrm{SD}=2.437)$ and post-test $(\mathrm{M}=41.29, \mathrm{SD}=3.407)$, while students in TG had a mean score of 35.92 with SD of 3.796 for pre-test, and a mean score of 44.92 with SD of 3.570 for post-test. Even though students in both groups achieved higher scores in their post-test, students in TG showed a better improvement with a mean difference between pre-test and post-test of 9.000, higher than those of CG (2.929). To decide whether there was a statistically significant difference between the mean scores of pre-test and post-test, a Paired Sample T-Test was applied.

TABLE 5. Paired-Samples T-Test

\begin{tabular}{|l|l|l|l|}
\hline Groups & $\mathrm{t}$ & $\mathrm{df}$ & Sig. (2-tailed) \\
\hline $\begin{array}{l}\text { CG pre-test }- \text { post- } \\
\text { test }\end{array}$ & -2.905 & 13 & 0.012 \\
\hline $\begin{array}{l}\text { TG pre-test }- \text { post- } \\
\text { test }\end{array}$ & -6.226 & 12 & 0.000 \\
\hline
\end{tabular}


Table 5 illustrates the p-value for both groups. The value was 0.012 and 0.000 for CG and TG respectively, which was less than the significance value of 0.05 . This indicated that there was a statistically significance difference between the pretest and post-test for both CG and TG. This implied that in both groups, students got significantly higher score in post-test after joining the training program.

TABLE 6. Independent-Sample T-Test
\begin{tabular}{|l|l|l|l|l|l|}
\hline & F & Sig. & t & df & $\begin{array}{l}\text { Sig. } \\
(2-\text { tailed })\end{array}$ \\
\hline Equal variances assumed & 0.085 & 0.773 & -2.709 & 25 & 0.012 \\
\hline Equal variances not assumed & & & -2.704 & 24.623 & 0.012 \\
\hline
\end{tabular}

To answer the first research question whether the implementation of Classcraft significantly affected the grammar performance of adult learners, an independent sample T-test was employed. Table 6 demonstrated that the p-value (sig 2-tailed) was lower than the significance level at $5 \%(0.012<0.05)$ revealing that the implementation of Classcraft had a significantly positive effect on enhancing grammar performance of adult learners compared to the traditional way of teaching.

TABLE 7. Results of Questionnaire on Students' Attitude towards Classcraft

\begin{tabular}{|l|l|l|l|}
\hline Statements & Mean & SD \\
\hline 1. & $\begin{array}{l}\text { This technique made the course more } \\
\text { fun }\end{array}$ & 4.385 & 0.65 \\
\hline 2. & I like competition on this technique. & 4.077 & 0.64 \\
\hline 3. & $\begin{array}{l}\text { This technique increased engagement in } \\
\text { the class. }\end{array}$ & 4.462 & 0.52 \\
\hline 4. & $\begin{array}{l}\text { This technique increased my interest in } \\
\text { the lessons. }\end{array}$ & 4.231 & 0.6 \\
\hline 5. & $\begin{array}{l}\text { This technique enabled me to learn } \\
\text { better. }\end{array}$ & 4.154 & 0.55 \\
\hline 6. & $\begin{array}{l}\text { This technique is suitable for language } \\
\text { class. }\end{array}$ & 4.231 & 0.44 \\
\hline 7. & $\begin{array}{l}\text { I want this technique to be used in other } \\
\text { courses. }\end{array}$ & 4.077 & 0.49 \\
\hline \multicolumn{2}{|l|}{ Average } & 4.231 & 0.56 \\
\hline
\end{tabular}

To answer the second research question, a questionnaire was given at the end of the course. Table 8 shows the result of the questionnaire. The average mean score of the questionnaire was 4.231 indicating that overall, students had positive attitude towards the use of Classcraft in the class. Item number 3 (This technique increased engagement with the class) had the highest mean score (4.462) followed by item number 1 (This technique made the course more fun) with the mean score of 4.385 . Item number 2 (I like competition on this technique) and item number 7 (I want this technique to be used in other courses) had the lowest mean score (4.077).

\section{DISCUSSION}

This study aims to identify the effect of using Classcraft to improve grammar performance of adult learners. The result confirms that the implementation of Classcraft indeed produces a better grammar performance compared to the usual teaching technique. This finding is in line with the findings of previous studies that explore the effect of using gamification in language learning [55,56]. Similarly, [11]. [14,15] conducted research on the effect of gamification on grammar performance resulting in the conclusion that gamification did improve grammar performance. Likewise, research carried out by Ge [51] demonstrated that applying reward strategies, one of gamification components, substantially improved adult learners' performance.

Better grammar performance in this study is possibly attributable to the fact that adult learners learn a lot from the review activities conducted through competition [57]. The result of students' questionnaire also supports this claim. Students' had a positive attitude towards item number 2 (I like competition on this technique) with a high mean score (4.077) showing that most students have a competitive drive In the Boss Battle activity, students review the lesson taught through a 
competition, be it with other classmates individually, or with other teams in the class. The competition is not a direct rivalry between peers or between teams as the goal in Boss Battle is to defeat the monster together through collaboration of all students in the class by answering questions. In spite of that, individuals or teams (depending on the mode selected by the teacher) will gain more XP if they answer the questions correctly and will lose their HP if their answers are incorrect leading to a match between attaining more XP and avoid losing more HP.

The ability to choose between individual or team mode in Boss Battle allows teachers to control the atmosphere in the class. If the taught materials are arduous, teachers can choose the team mode so that students can discuss the answers with their friends. Thus, learners who are having difficulty with the materials can learn from their friends during the discussion and even if students give an incorrect answer, the members of the team share the same feeling. This way, the heavy atmosphere when an individual feels embarrassed for choosing an incorrect answer can be avoided. Merriem [58] argue that a successful adult learning process is dependent to the environment (physical, psychological, and social) where the process occurs. They reveal that the class atmosphere where a teacher provides warm and reassuring ambiance to attend to adult learner's feeling of fear and doubt can reduce their discomfort and diversion. Knowles et al. [59] claim that if the class atmosphere does not pressurize adult learners to lose control over the learning process, it is likely that they will succeed in obtaining new knowledge. Additionally, Huang and Soman [60] point out that one of the purposes of gamification is to lessen negative emotions usually present in a traditional way of education. They further explain that gamification allows learners master the materials taught using the technique of learning by mistake without feeling embarrassed.

Teachers can also ask students to choose whether they want to play individually or in teams. This gives students a sense of self confidence to control their own learning process. If students think that they have already mastered the materials, they will choose to play individually and if most students think that the materials are too difficult, they can decide to play in teams. From a perspective of Self Determination Theory, this is related to human's need for autonomy
[47]. Autonomy means the ability to come to a decision based on one's interest. To such a degree, this makes learners intrinsically motivated since they can oversee their own learning course. Leaning [42] reports that one of the advantages of applying gamification in an educational setting is more ownership of learning. Furthermore, Skinner et al.[61] state that autonomy can raise students' engagement behaviorally and emotionally. Being autonomous and self-directed are characteristics of adult learners that directed them to choose their own path and govern their learning process [8] [35]. Adult learners cherish the control over the learning process and are in favor of making the learning process their possession [59].

Another feature of gamification that helps creating a stimulating learning environment is the game elements attached to it. Elements like point, badge, and leaderboard motivate learners to achieve a better performance. Gaining more points after giving a correct answer or obtaining a badge after completing certain tasks contribute to the feeling of recognition. Bai et al. [62] conducted a qualitative study on 24 articles about the effect of gamification on learning outcomes. They attributed the positive impact of gamification on learning performance to three specific reasons, one of which is gamification can fulfill learners' need for recognition. Cavalcanti et al.[63] and Goehle [64] reported that points or badges can amplify learners' sense of attainment and recognition for fulfilling a certain task. Recognition provides a sense of pride leading to a continuous participation and improved learning [65].

Increased performance on the post-test of the treatment group can also be attributed to immediate feedback provided by gamification. Conformational feedback denoting the correct answer from the incorrect one [41] satisfies learners curiosity by giving direct feedback of their answer. Points obtained from answering questions correctly are also a feedback for learners on their achievements or mastery of the materials taught. Viewed from theoretical perspective of Self Determination Theory, feedback can fulfill learners need for competence [10]. Landers et al. [65] revealed that competence fulfillment can enhance student task performance as well as build up enjoyment.

Another important feature offered by Classcraft is the opportunity to play the game as an individual or as a team member. When playing as an individual, 
it serves to satisfy an individual recognition. However, being a team member gives learners a sense of belonging to a group. It serves to fulfill the need of relatedness in the viewpoint of Self Determination Theory. According to Ryan and Deci [47], relatedness means human's need to work or bond with other people. An increased relatedness stimulates the feeling of enjoyment and boosts student participation in playing the game [61]. Adult learners are indeed more cooperative, which stems from their observation of the situations they are in [7]. Their perceiving nature of the surroundings is drawn from life experiences as adults. Adults' experiences could influence the learning strategies utilized by the teacher in the learning process and this experience may enhance their grammar performance as adult learners partake in group or peer activities [66].

The result of the questionnaire also demonstrates that adult learners have positive attitudes towards the implementation of Classcraft in the class with item number 3 (This technique increased engagement in the class) showing the highest number of mean of 4.462. This confirms the previous research stating that the more learners engage themselves in playing the game, the more knowledgeable they become [11]. As such, implementing gamification in the classroom produces more motivation, involvement, excitement compared to the traditional way of learning resulting in a better grammar performance.

\section{CONCLUSION AND RECOMMENDATION FOR FUTURE RESEARCH}

The finding of this study affirms that implementing Classcraft in the classroom could enhance grammar performance of adult learners. This suggesting that adult learners whose characteristics are goaloriented, autonomous, and self-directed, need to have their learning process designed to suit their needs. A learning process that gives adult learners a sense of competitiveness, autonomy, recognition, competence, and relatedness can enhance adult learners' learning performance. Classcraft provides those features and can convert boring and arduous grammar exercises into an exhilarating and comprehensible activity. Even though gamification can provide a better learning environment for adult learners, it is only an instrument to help make the learning atmosphere more pleasing. The teacher is still the boss who exploits the features attributed to gamification and utilize those features to the best of their flairs. "The purpose of teaching is to facilitate personal growth and development that impact the professional, social, and political aspects of learners" [67]. Irrespective of what platform teacher uses and how the class is arranged, it is imperative that the design and approach for the learning process be in the best interest of adult learners.

Despite its effectiveness in enhancing grammar performance, some issues concerning the use of Classcraft in the class needed to be attended to. First, using Classcraft in every review exercise might raise anticipation from the students and make them loose interest to play the game. Future research can be conducted by combining different gamification platforms into one classroom for different learning activities to keep learners' enthusiasm by maintaining elements of surprise. Next, other researchers could conduct a study to investigate the effect of the duration of the application of gamification. The short period of time in this study can possibly make learners feel enthusiast due to its novelty factor. As gamification is a new learning technique for them, they invest their time in becoming accustomed to the new instrument. Lastly, future research can be carried out to know whether the effect of gamification applies across proficiency level by comparing students from low proficiency level and high proficiency level.

\section{REFERENCES}

[1] L. Cam and T. M. T. Tran, "An evaluation of using games in teaching English grammar for first year English-majored students at Dong Nai Technology University," Int. J. Learn. Teach. Educ. Res., vol. 16, no. 7, 2017, [Online]. Available: https://www.ijlter.org/index.php/ijlter/articl e/view/962.

[2] Y. Türkmen, "The effects of using online concordancers on teaching grammar," $J$. Grad. Sch. Sch. Sci. Ataturk Univ., vol. 20, pp. 145-152, 2016, [Online]. Available: https://www.researchgate.net/publication/3 01590462_The_Effects_of_Using_Online_ Concordancers_on_Teaching_Grammar.

[3] Ç. T. Mart, "Teaching grammar in context: Why and how?," Theory Pract. Lang. Stud., vol. 3, no. 1, pp. 124-129, 2013, doi: 10.4304/tpls.3.1.124-129. 
[4] V. I. Ikpia, "The attitudes and perceptions of non-native English speaking adults toward explicit grammar instruction," Humanit. Rev. J., vol. 5, no. 1, 2005, doi: 10.4314/hrj.v5i1.5957.

[5] A. G. Rodriguez, "Teaching grammar to adult English language learners: Focus on form," Center for Adult English Language Acquisition, 2009. https://www.cal.org/caelanetwork/pdfs/Tea chingGrammarFinalWeb.pdf.

[6] Z. Saeedi and A. Biri, "The application of technology in teaching grammar to EFL learners: The role of animated sitcoms," Teach. English with Technol., vol. 16, no. 2, pp. 18-39, 2016, [Online]. Available: https://www.tewtjournal.org/issues/volume2016/volume-2016-issue-2/.

[7] M. Cozma, "The challenge of teaching English to adult learners in today's world," Procedia - Soc. Behav. Sci., vol. 197, no. February, pp. 1209-1214, 2015, doi: 10.1016/j.sbspro.2015.07.380.

[8] N. A. Biryukova, S. L. Yakovleva, T. V. Kolesova, L. V. Lezhnina, and A. A. Kuragina, "Understanding adult learners as a core principle of effective ESL-educators," Rev. Eur. Stud., vol. 7, no. 8, pp. 137-146, 2015, doi: 10.5539/res.v7n8p147.

[9] M. S. Kuo and T. Y. Chuang, "How gamification motivates visits and engagement for online academic dissemination - An empirical study," Comput. Human Behav., vol. 55, pp. 16-27, 2016, doi: 10.1016/j.chb.2015.08.025.

[10] M. Sailer, J. U. Hense, S. K. Mayr, and H. Mandl, "How gamification motivates: An experimental study of the effects of specific game design elements on psychological need satisfaction," Comput. Human Behav., vol. 69, pp. 371-380, 2017, doi: 10.1016/j.chb.2016.12.033.

[11] S. Wichadee and F. Pattanapichet, "Enhancement of performance and motivation through application of digital games in an english language class," Teach. English with Technol., vol. 18, no. 1, pp. 7792, 2018, [Online]. Available: https://www.tewtjournal.org/issues/volume18/issue-1/.

[12] B. Icard, "Educational technology best practices," Int. J. Instr. Technol. Distance Learn., vol. 11, no. 3, pp. 37-42, 2014,
[Online].

Available:

https://itdl.org/Journal/Mar_14/Mar14.pdf.

[13] J. Hamari, J. Koivisto, and H. Sarsa, "Does gamification work? - A literature review of empirical studies on gamification," Proc. Annu. Hawaii Int. Conf. Syst. Sci., pp. 30253034, 2014, doi: 10.1109/HICSS.2014.377.

[14] H. Hashim, K. R. M. Rafiq, and M. Md. Yunus, 'Improving ESL learners' grammar with gamified-learning," Arab World English J., vol. Special Is, no. 5, pp. 41-50, 2019, doi: 10.24093/awej/call5.4.

[15] E. Zarzycka-Piskorz, "Kahoot it or not?: Can games be motivating in learning grammar?," Teach. English with Technol., vol. 16, no. 3, pp. 17-36, 2016, [Online]. Available: https://www.tewtjournal.org/issues/volume2016/volume-2016-issue-3/.

[16] D. Goshevski, J. Veljanoska, and $\mathrm{H}$. Hatziapostolou, "A review of gamification platforms for higher education," ACM Int. Conf. Proceeding Ser., vol. Part F1309, 2017, doi: 10.1145/3136273.3136299.

[17] F. C. Eugenio and A. J. T. Ocampo, "Assessing classcraft as an effective gamification app based on behaviorism learning theory," ACM Int. Conf. Proceeding Ser., vol. Part F1479, pp. 325329, 2019, doi: 10.1145/3316615.3316669.

[18] D. A. Haris and E. Sugito, "Analysis of factors affecting user acceptance of the implementation of ClassCraft E-Learning: Case studies faculty of information technology of Tarumanagara university," ICACSIS 2015 - 2015 Int. Conf. Adv. Comput. Sci. Inf. Syst. Proc., pp. 73-78, 2016,

doi: 10.1109/ICACSIS.2015.7415161.

[19] Á. D. Montosa Lirola, "Gamification and motivation in the EFL classroom: A surveybased study on the use of classcraft," Universitat de les Illes Balears, 2018.

[20] S. Papadakis and M. Kalogiannakis, "Using gamification for supporting an introductory programming course. The case of Classcraft in a secondary education classroom," in Interactivity, Game Creation, Design, Learning, and Innovation, vol. 229, Springer, Cham, 2018, pp. 366-375.

[21] M. Schatten and M. Schatten, "Gamification of game programming education: A case study in a Croatian high school," in Central European Conference on Information and Intelligent Systems, 2019, no. 1, pp. 13-18, 
[Online].

Available:

https://search.proquest.com/docview/23666 61050/fulltextPDF/C4695CE77C7248.

[22] S. Frazier and H. D. Brown, "Teaching by principles: An interactive approach to language pedagogy," TESOL $Q$., vol. 35, no. 2, pp. 341-342, 2001, doi: $10.2307 / 3587655$.

[23] S. Thornbury, How to teach grammar. Pearson Education, Longman, 2002.

[24] D. Larsen-Freeman, "Teaching and testing grammar," in The Handbook of Language Teaching, Michael H. Long Catherine J. Doughty, Ed. Blackwell Publishing Ltd, 2009.

[25] J. C. Richards and R. Reppen, "Towards a pedagogy of grammar instruction," RELC J., vol. 45, no. 1, pp. 5-25, 2014, doi: $10.1177 / 0033688214522622$.

[26] J. Burgess and S. Etherington, "Focus on grammatical form: Explicit or implicit?," System, vol. 30, no. 4, pp. 433-458, 2002, doi: 10.1016/S0346-251X(02)00048-9.

[27] H. Fatemipour and S. Hemmati, "Impact of consciousness-raising activities on young English language learners' grammar performance," English Lang. Teach., vol. 8, no. 9, 2015, doi: 10.5539/elt.v8n9p1.

[28] Y. Tiarina, H. Syarif, J. Jufrizal, and Y. Rozimela, "Students' need on basic English grammar teaching material based on interactive multimedia: An innovative design," COUNS-EDU Int. J. Couns. Educ., 2019, doi: 10.23916/0020190419310.

[29] M. H. Long, "Does second language instruction make a difference? A review of research," TESOL Q., vol. 17, no. 3, pp. 359-382, 1983, doi: 10.2307/3586253.

[30] R. Ellis, "Does form-focused instruction affect the acquisition of implicit knowledge?: A review of the research," Stud. Second Lang. Acquis., vol. 24, no. 2, pp. 223-236, 2002, doi: $10.1017 / \mathrm{s} 0272263102002073$.

[31] H. Nassaji and S. Fotos, "Current developments in research on the teaching of grammar," Annu. Rev. Appl. Linguist., vol. 24, pp. 126-145, 2004, doi: 10.1017/s0267190504000066.

[32] Y. Özkan, "Utilization of news articles in English grammar teaching," Trak. Univ. J. Soc. Sci., vol. 17, no. 1, pp. 49-59, 2015, [Online].

Available: https://dergipark.org.tr/tr/download/articlefile/321331.

[33] B. Azar, "Grammar-Based Teaching: A Practitioner's Perspective.," TESL-EJ, vol. 11, no. 2, 2007, [Online]. Available: http://tesl-ej.org/ej42/a1.pdf.

[34] W. Richard, J., \& Renandya, Methodology in Language Teaching: An Anthology of Current Practice (Cambridge Professional Learning). Cambridge: Cambridge University Press, 2002.

[35] M. S. Knowles, Andragogy in action: Applying modern principles of adult education. Jossey-Bass, 1984.

[36] S. Deterding, D. Dixon, R. Khaled, and L. Nacke, "From game design elements to gamefulness: Defining 'gamification,"' 2011, doi: 10.1145/2181037.2181040.

[37] F. Groh, "Gamification: State of the Art Definition and Utilization," 2012.

[38] B. Burke, Gamify. How gamification motivates people to do extraordinary things. Brookline: Bibliomotion, Inc., 2014.

[39] J. McGonigal, Reality is broken: Why games make us better and how they can change the world. New York: Penguin Press, 2011.

[40] B. Kim, "Harnessing the power of game dynamics: Why, how to, andhow not to gamify the library experience," Coll. Res. Libr. News, vol. 73, no. 8, pp. 465-469, 2012, doi: 10.5860/crln.73.8.8811.

[41] K. M. Kapp, The gamification of learning and instruction: Game-based methods and strategies for training and education. John Wiley \& Sons, 2012.

[42] M. Leaning, "A study of the use of games and gamification to enhance student engagement, experience and achievement on a theory-based course of an undergraduate media degree," J. Media Pract., vol. 16, no. 2, pp. 155-170, 2015, doi: 10.1080/14682753.2015.1041807.

[43] J. J. Lee and J. Hammer, "Gamification in education: What, how, why bother?," Acad. Exch. Q., vol. 15, no. 2, pp. 1-5, 2011, [Online]. Available: https://www.researchgate.net/publication/2 58697764_Gamification_in_Education_Wh at_How_Why_Bother.

[44] J. Simões, R. D. Redondo, and A. F. Vilas, "A social gamification framework for a K-6 learning platform," Comput. Human Behav., vol. 29, no. 2, pp. 345-353, 2013, doi: 10.1016/j.chb.2012.06.007. 
[45] I. Glover, "Play as you learn: Gamification as a technique for motivating learners," in Proceedings of EdMedia 2013--World Conference on Educational Media and Technology, 2013, pp. 1999-2008, [Online]. Available:

https://www.researchgate.net/publication/2 66853048_Play_As_You_Learn_Gamificat ion_as_a_Technique_for_Motivating_Lear ners.

[46] E. Sanchez, S. Young, and C. Jouneau-Sion, "Classcraft: from gamification to ludicization of classroom management," Educ. Inf. Technol., vol. 22, no. 2, pp. 497513, 2017, doi: 10.1007/s10639-016-94896.

[47] R. M. Ryan and E. L. Deci, "Intrinsic and extrinsic motivations: Classic definitions and new directions," Contemp. Educ. Psychol., vol. 25, no. 1, pp. 54-67, 2000, doi: 10.1006/ceps.1999.1020.

[48] C. Holman, S. J. Aguilar, A. Levick, J. Stern, B. Plummer, and B. Fishman, "Planning for success: How students use a grade prediction tool to win their classes," 2015, doi: 10.1145/2723576.2723632.

[49] M. Ortiz-Rojas, K. Chiluiza, and M. Valcke, "Gamification and learning performance: A systematic review of the literature," in Proceedings of the 11th European Conference on Games Based Learning, ECGBL 2017, 2017, no. October, pp. 515522, [Online]. Available: https://www.researchgate.net/publication/3 20372825_Gamification_and_learning_perf ormance_A_systematic_review_of_the_lite rature.

[50] A. Mora, E. Planas, and J. Arnedo-Moreno, "Designing game-like activities to engage adult learners in higher education," in TEEM '16: Proceedings of the Fourth International Conference on Technological Ecosystems for Enhancing Multiculturality, 2016, vol. 02-04-Nove, pp. 755-762, doi: $10.1145 / 3012430.3012603$

[51] Z. G. Ge, "The impact of a forfeit-or-prize gamified teaching on e-learners' learning performance," Comput. Educ., vol. 126, pp. 143-152, 2018, doi: 10.1016/j.compedu.2018.07.009.

[52] D. Ary, L. C. Jacobs, C. K. S. Irvine, and D. A. Walker, Introduction to Research in Education. Cengage Learning, 2018.
[53] B. W. Yap and C. H. Sim, "Comparisons of various types of normality tests," J. Stat. Comput. Simul., vol. 81, no. 12, pp. 21412155, 2011, doi: 10.1080/00949655.2010.520163

[54] H. Coolican, Research methods and statistics in psychology. Routledge, 2018.

[55] J. F. Figueroa-Flores, "Using Gamification to enhance second language learning," Digit. Educ. Rev., vol. 27, no. 21, pp. 32-54, 2015, [Online].

Available: https://www.researchgate.net/publication/2 78328067_Using_Gamification_to_Enhanc e_Second_Language_Learning.

[56] M. Veljković Michos, "Gamification in foreign language teaching: Do you Kahoot?," 2017, doi: 10.15308/sinteza2017-511-516.

[57] B. Kim, "Designing gamification in the right way," Libr. Technol. Rep., vol. 51, no. 2, pp. 29-35, 2015, [Online]. Available: https://journals.ala.org/index.php/ltr/article/ view/5632/6952.

[58] S. B. Merriam and R. G. Brockett, The profession and practice of adult education: An introduction. Jossey-Bass, 1997.

[59] M. Knowles, E. Holton III, and R. Swanson, "Andragogy in practice," in The adult learner.: The definitive classic in adult education and human resources development., Elsevier Inc., 2005, pp. 138162.

[60] W. H. Huang and D. Soman, "A practitioner's guide to gamification of education," 2013. doi: 10.1111/j.14678535.2011.01259.x.

[61] E. Skinner, C. Furrer, G. Marchand, and T. Kindermann, "Engagement and Disaffection in the Classroom: Part of a Larger Motivational Dynamic?," J. Educ. Psychol., vol. 100, no. 4, pp. 765-781, 2008, doi: 10.1037/a0012840.

[62] S. Bai, K. F. Hew, and B. Huang, "Does gamification improve student learning outcome? Evidence from a meta-analysis and synthesis of qualitative data in educational contexts," Educ. Res. Rev., vol. 30, p. 100322, 2020, doi: 10.1016/j.edurev.2020.100322.

[63] C. C. Cavalcanti, A. Filatro, and W. A. Presada, "Gamification design for tutor education in an online course," ETD - Educ. Temática Digit., vol. 20, no. 4, pp. 887-904, 2018, doi: 10.20396/etd.v20i4.8648223. 
[64] G. Goehle, "Gamification and web-based homework," Probl. Resour. Issues Math. Undergrad. Stud., vol. 23, no. 3, pp. 234246, 2013, doi: 10.1080/10511970.2012.736451.

[66] D. Finn, "Principles of adult learning: An ESL context," J. Adult Educ., vol. 40, no. 1, pp. 34-39, 2011, [Online]. Available: https://eric.ed.gov/?id=EJ960967.

[65] R. N. Landers, K. N. Bauer, R. C. Callan, and M. B. Armstrong, "Psychological theory and the gamification of learning," in Gamification in Education and Business, M. W. Galbraith, Adult learning methods: A guide for effective instruction, Third Edition. Malabar, FL: Krieger Publishing Company, Reiners T., Springer, Cham, 2015. 